\title{
In vitro evaluation of methicillin-resistant and methicillin-sensitive Staphylococcus aureus susceptibility to Saudi honeys
}

\author{
Muhammad Barkaat Hussain ${ }^{1 *}$, Yasser Mahmoud Kamel', Zia Ullah', Asif Ahmad Mohamad Jiman-Fatani ${ }^{2}$ and \\ Ansar Shafiq $\mathrm{Ahmad}^{3}$
}

\begin{abstract}
Background: Honey has been increasingly recognized as a potential therapeutic agent for treatment of wound infections. There is an urgent need for assessment and evaluation of the antibacterial properties against wound pathogens of honeys that have not yet been tested.
\end{abstract}

Methods: Ten Saudi honeys collected from different geographical locations were screened initially for their antibacterial potential against methicillin-resistant Staphylococcus aureus (MRSA) and methicillin-sensitive Staphylococcus aureus (MSSA) by the agar well diffusion method. Manuka honey (UMF-12) was used for comparison. Of the tested honeys, the honey that exhibited the greatest antibacterial activity in the agar well diffusion assay was further evaluated for its minimum inhibitory concentration (MIC) against ten MRSA clinical isolates and three American Type Culture Collection (ATCC) reference strains by the microbroth dilution method.

Results: Locally produced honeys exhibited variable antibacterial activity against the tested isolates in the agar well diffusion assay. They were unable to exhibit antibacterial activity against MSSA and MRSA at 25\% dilutions (w/v) in catalase solution. However, Sumra and Talha honeys showed a zone of inhibition at $50 \%$ dilutions (w/v) in catalase solution. This finding means that both honeys possess weak non-peroxide-based antibacterial activity. Moreover, Sumra honey showed a larger inhibition zone at 50 and 25\% dilutions (w/v) in distilled water than Manuka honey against both MSSA and MRSA. This result demonstrates that Sumra honey has more hydrogen peroxide-related antibacterial activity or total antibacterial activity than Manuka honey. In addition, MIC results obtained through a microbroth dilution assay showed that Sumra honey inhibited the growth of all MRSA clinical isolates $(n=10)$ and reference strains [MRSA (ATCC 43300) and MSSA (ATCC 29213)] at lower concentrations (12.0\% v/v) than those required for Manuka honey-mediated inhibition $(14.0 \% \mathrm{~V} / \mathrm{V})$. This result means that Sumra honey has more peroxide or synergistic antibacterial activity than Manuka honey. An equivalent MIC (15.0\% v/v) was observed for E. coli (ATCC 25922) between Manuka honey and Sumra honey.

Conclusions: Sumra honey may be used as an alternative therapeutic agent for infected wounds and burns, where additional hydrogen peroxide-related antibacterial activity is needed. In the future, the physiochemical characteristics of Sumra honey may be evaluated and standardized.

Keywords: Wounds, Infection, Antibacterial activity, Sumra honey, MRSA

\footnotetext{
* Correspondence: mbhussain1@kau.edu.sa

'Department of Microbiology, Faculty of Medicine, King Abdulaziz University,

Rabigh Branch 21589, Saudi Arabia

Full list of author information is available at the end of the article
}

(c) The Author(s). 2019 Open Access This article is distributed under the terms of the Creative Commons Attribution 4.0 International License (http://creativecommons.org/licenses/by/4.0/), which permits unrestricted use, distribution, and reproduction in any medium, provided you give appropriate credit to the original author(s) and the source, provide a link to the Creative Commons license, and indicate if changes were made. The Creative Commons Public Domain Dedication waiver (http://creativecommons.org/publicdomain/zero/1.0/) applies to the data made available in this article, unless otherwise stated. 


\section{Background}

Human isolates of methicillin-resistant Staphylococcus aureus (MRSA) are some of the bacteria most frequently involved in wound infections [1]. MRSA infection is associated with a prolonged healing duration, a rise in postoperative complications, and increased mortality [2]. According to a recent meta-analysis report extracted from seven articles, the overall MRSA prevalence in Saudi Arabia is 38\%, which is quite high in comparison with Gulf Corporation Council (GCC) countries, with Kuwait having the lowest (3.3\%) [3, 4]. A significant variation exists in the prevalence of MRSA worldwide, which ranges from 12 to $73 \%$. A cross-sectional study in nine European countries revealed that Hungary had a prevalence rate of $12.1 \%$ and Sweden had a prevalence rate of $29.4 \%$ [5]. New antimicrobial agents are not being produced as quickly as they are needed [6,7]. Honey, in this regard, is considered to be a promising agent [8]. Honeys collected from different areas have been demonstrated to have substantial antibacterial effects on infected wounds and burns $[9,10]$. In addition to its potent antibacterial effects, honey is also useful in reducing inflammation and promoting wound debridement, angiogenesis, granulation, and epithelialization [11]. Its effectiveness has been shown in multiple reports regarding a variety of different wounds, including infected wounds, soft tissue infections, burns and skin ulcers [12-14].

A number of clinical trials have shown that the use of honey as a wound dressing is better than the use of topical or systemic antibiotics, including for diabetic foot ulcers [15-18]. Manuka honey-impregnated dressings are effective in even recalcitrant cases that had been previously treated with conventional modalities, such as systemic antibiotic therapy, negative pressure vacuumassisted dressings, continuous dressing change with local debridement and maggot treatment [19]. A Cochrane systematic review by Jull et al. (2015) concluded that the use of honey in cases other than partial thickness burns and infected postoperative wounds is not supported by high-quality evidence and therefore does not have a strong basis for decision making [20]. One clinical trial has shown that honey dressings did not enhance venous leg ulcer healing in comparison with conventional treatment; rather, honey treatment was associated with more adverse effects and involved higher cost than conventional therapy [21].

Honey has demonstrated multiple antibacterial properties against different wound pathogens, but only a narrow range of medically graded honeys are available for wound management [22-25]. Moreover, certified honeys (approved and registered by health regulatory authorities) are not easily accessible and are generally costly. Therefore, it is important to evaluate new honeys with high levels of antibacterial activity that are locally produced and affordable. Previously, we reported the susceptibility of multidrug-resistant Salmonella typhi to honey and conducted a clinical trial of impregnated honey dressings for the treatment of diabetic foot ulcers $[17,26]$. Honey is widely consumed in Saudi Arabia as a preventive and curative agent for several human illnesses in addition to its popular usage as food [27]. A number of studies have been performed in Saudi Arabia regarding the antibacterial properties of indigenous honey against different bacterial isolates [28-32]. However, in most of the previous studies, the precise geographical locations of tested honeys were not mentioned, and their antibacterial activity was not compared with medically graded honey $[28,29]$. Therefore, keeping in view of these limitations, we tested Saudi honeys with known geographical origins and compared their antibacterial activity with medically graded Manuka honey.

\section{Methods \\ Honey samples}

Ten honey samples produced by Apis mellifera jemenitica were collected from different geographical locations of Saudi Arabia (Table 1). Apis mellifera jemenitica is the native bee in the Arabian Peninsula and is tolerant to local dry and hot weather conditions. The honeys were kept in brown bottles at room temperature, and their sterility was determined on blood agar medium. A loopful $(10 \mu \mathrm{l})$ quantity of honey from each honey sample was inoculated on blood agar plates. The streaked plates were incubated aerobically at $37^{\circ} \mathrm{C}$ and examined for any growth after $24 \mathrm{~h}$. Medically graded Manuka honey (Molan Gold Standard 12 plus, methylglyoxal$400 \mathrm{mg}$ per $\mathrm{kg}$, Watson and Son-New Zealand) purchased from Al-Nahdi Pharmacy, Jeddah, was used for comparison. Artificial honey was also used to evaluate the role of sugar in the antibacterial potential of honey. The artificial honey was prepared by a previously described method [33].

\section{Bacterial strains}

Thirteen bacterial isolates comprising ten clinical isolates of MRSA and three standard strains (ATCC) were used (Table 4). The clinical isolates and reference strains were obtained from King Abdulaziz University Hospital, Clinical and Molecular Microbiology Laboratory, Jeddah, Saudi Arabia.

\section{Agar well diffusion assay}

The agar well diffusion method was used for an initial screening of honey samples, as performed by Allen et al, with slight adjustments [34]. The assay is the most frequently used method for assessing the antibacterial potency of honey because of its ease, low cost and rapidity [35]. The details of this procedure were kindly 
Table 1 Geographical location, floral source and harvesting season of Saudi honeys

\begin{tabular}{|c|c|c|c|c|}
\hline Code no. & Name of honey & Floral source & Geographical location and coordinates & Harvesting season \\
\hline $\mathrm{H} 01$ & Sidr & Ziziphus spina-christi & $\begin{array}{l}\text { Al-Baha, Baraha Magamaa } \\
20^{\circ} 0^{\prime} 32.94^{\prime \prime} \mathrm{N} 41^{\circ} 27^{\prime} 53.82^{\prime \prime} \mathrm{E}\end{array}$ & October, 2016 \\
\hline $\mathrm{H} 02$ & Talha & Acacia sp. & $\begin{array}{l}\text { Al-Baha, Beta Valley } \\
20.0129^{\circ} \mathrm{N} 41.4677^{\circ} \mathrm{E}\end{array}$ & April, 2016 \\
\hline $\mathrm{H} 03$ & Sumra & Acacia tortilis & $\begin{array}{l}\text { Al-Baha, Beta Valley } \\
20.0129^{\circ} \mathrm{N} 41.4677^{\circ} \mathrm{E}\end{array}$ & April, 2016 \\
\hline $\mathrm{H} 04$ & Sidr & Ziziphus spina-christi & $\begin{array}{l}\text { Al-Baha, Baljurashi } \\
19^{\circ} 50^{\prime} 33.828^{\prime \prime} \mathrm{N} 41^{\circ} 33^{\prime} 43.848^{\prime \prime} \mathrm{E}\end{array}$ & October, 2015 \\
\hline H05 & Talha & Acacia sp. & $\begin{array}{l}\text { Al-Baha, Baljurashi } \\
19^{\circ} 50^{\prime} 33.828^{\prime \prime} N 41^{\circ} 33^{\prime} 43.848^{\prime \prime} \mathrm{E}\end{array}$ & April, 2015 \\
\hline H06 & Sumra & Acacia tortilis & $\begin{array}{l}\text { Al-Mukhwah, } \\
19^{\circ} 47^{\prime} 21.48^{\prime \prime} \mathrm{N} 41^{\circ} 26^{\prime} 22.164^{\prime \prime} \mathrm{E}\end{array}$ & April, 2015 \\
\hline H07 & Zahoor & Mixed flora & $\begin{array}{l}\text { Ali-al-Saalam, Al-Hasa-Qweiba } \\
30^{\circ} 57^{\prime} 25.74^{\prime \prime} \mathrm{N} 35^{\circ} 45^{\prime} 46.26^{\prime \prime} \text { E }\end{array}$ & March, 2015 \\
\hline H08 & Zahoor & Mixed flora & $\begin{array}{l}\text { Ali-al-Khamis, Al-Hasa-Qweiba } \\
30^{\circ} 41^{\prime} 32.676^{\prime \prime} \mathrm{N} 35^{\circ} 51^{\prime} 51.732^{\prime \prime} \mathrm{E}\end{array}$ & March, 2015 \\
\hline H09 & Zahoor & Mixed flora & $\begin{array}{l}\text { Muhammad, Al-Hasa-Qweiba } \\
30^{\circ} 41^{\prime} 32.676^{\prime \prime} \mathrm{N} 35^{\circ} 51^{\prime} 51.732^{\prime \prime} \mathrm{E}\end{array}$ & March, 2015 \\
\hline $\mathrm{H} 11$ & Sidr & Ziziphus spina-christi & $\begin{array}{l}\text { Al-Baha, Wadi Beedah and Mahshooqa } \\
20^{\circ} 0^{\prime} 32.94^{\prime \prime} \mathrm{N} 41^{\circ} 27^{\prime} 53.82^{\prime \prime} \mathrm{E}\end{array}$ & October, 2015 \\
\hline
\end{tabular}

provided by Kerry Allen (personal communication), Honey Research Unit, Waikato University, New Zealand.

Mueller-Hinton (MH) agar (Oxoid Ltd., UK) was used instead of nutrient agar because $\mathrm{MH}$ agar is the preferred medium for antibacterial testing according to the CLSI standard [36]. Second, we used vancomycin $(30 \mu \mathrm{g})$ as a positive control instead of $6 \%$ phenol. A catalase solution and sterile distilled water were used as negative controls.

On sheep blood agar plates, MRSA and MSSA were sub-cultured. From the overnight culture, a 0.5 McFarland turbidity suspension $(540 \mathrm{~nm})$ was prepared in tryptic soy broth using a colorimeter. A volume of $100 \mu \mathrm{l}$ of the culture (0.5 absorbance) was used to inoculate $150 \mathrm{ml}$ of $\mathrm{MH}$ medium for each culture. The cultures were kept at $45^{\circ} \mathrm{C}$ in a water bath for $25 \mathrm{~min}$ before inoculating with $100 \mu \mathrm{l}$ of each culture. Thoroughly mixed agar was poured into $90 \mathrm{~mm}$ diameter Petri dishes $\left(20 \mathrm{ml}\right.$ in each) and stored at $4{ }^{\circ} \mathrm{C}$ overnight. Five wells were made in the agar plate according to a standard template with a sterile $9 \mathrm{~mm}$ cork borer and were numbered at random.

From each honey sample, 50\% (w/v) honey dilutions were prepared in sterile purified water and catalase (Sigma C1345-10G, bovine liver, 5,000 units/mg). To prepare the catalase solution, $20 \mathrm{mg}$ of catalase was added to $10 \mathrm{ml}$ of sterile distilled water. Secondary honey solutions comprising 25\% (w/v) honey in sterile purified water and catalase solution were prepared from the primary solution. One hundred twenty microlitre solutions from each dilution were added to each allotted well, and the agar plates were placed in an incubator for $16 \mathrm{~h}$ at $35^{\circ} \mathrm{C}$. The inhibition zone was measured in $\mathrm{mm}$. Each experiment was performed in triplicate on the same day using three identical wells.

\section{Microbroth dilution assay}

MICs of Sumra, Manuka and artificial honey against all the clinical isolates of MRSA $(n=10)$ and three ATCC reference strains (Table 4 ) were determined by a microbroth dilution assay in sterile 96-well microtitre plates (Thermo Fisher Scientific, UK). A 50\% (v/v) stock solution of each honey sample was prepared by weighing $13.7 \mathrm{~g}$ of the honey and bringing the volume up to $20 \mathrm{ml}$ using Mueller Hinton $(\mathrm{MH})$ broth. Since honey is very viscous and it is difficult to pipette, it was weighed out. The density of honey was as assumed to be $1.37 \mathrm{~g} / \mathrm{ml}$ [37]. Further, twenty incremental dilutions (from 1 to $20 \% \mathrm{v} / \mathrm{v}$ ) were prepared in 96 -well microtitre trays by adding a calculated volume of honey from the $50 \%(\mathrm{v} / \mathrm{v})$ stock solution and a calculated volume of bacterial suspension $\left(5 \times 10^{5} \mathrm{CFU} / \mathrm{ml}\right)$ to obtain a final volume of $200 \mu \mathrm{l}$ in each allotted well. In previous studies, two-fold dilutions of honey were prepared in a microbroth dilution assay to determine the MICs of honey [38, 39]. However, in this study, $1 \%$ incremental dilutions were used to obtain more precise inhibitory concentrations of tested honey samples. However, 5\% incremental dilutions of artificial honey were prepared, ranging from 5 to $40 \%$.

Five isolated colonies were picked from overnight blood agar culture and inoculated into nutrient broth to obtain a 
turbidity matched with $0.5 \mathrm{McF}$ arland $\left(1 \times 10^{8} \mathrm{CFU} / \mathrm{ml}\right)$. Further dilutions of bacterial suspensions were performed in $\mathrm{MH}$ broth to obtain a final dilution of inoculums of $5 \times 10^{5} \mathrm{CFU} / \mathrm{ml}$. Positive control wells contained $\mathrm{MH}$ broth with the bacterial suspension, and negative wells contained $\mathrm{MH}$ broth only. The microtitre plates were incubated aerobically at $37^{\circ} \mathrm{C}$ for $16 \mathrm{~h}$ in a stationary incubator and observed visually for the absence or presence of growth by comparison to the positive and negative controls. The minimum inhibitory concentrations were calculated as the lowest concentration of honey that prevented visible bacterial growth after overnight incubation. All experiments were performed in triplicate on the same day using three identical wells.

\section{Statistical analysis}

The data were analysed by IBM Statistical Package for Social Sciences software (SPSS 23.0). The arithmetic mean of the inhibition zone of each honey sample and the MICs of the tested honeys were calculated. The differences among the mean MICs of the tested honeys were calculated by applying the Kruskal-Wallis test. However, the Bonferroni post hoc test was applied for pair-wise comparisons between different honeys. The results were considered significant at $p<0.05$.

\section{Results}

All locally produced honeys showed antibacterial activity against the MSSA and MRSA clinical isolates and ATCC reference strains, MRSA (43300), MSSA (43300) and Escherichia coli (25922), in an agar well diffusion assay (Tables 2 and 3). However, there was much variation in the potency of the antibacterial activity of the tested honeys. The variation existed not only between different floral honeys but also between honeys with the same floral origins (Tables 2 and 3). For instance, Sumra honey (H03) collected from Al-Baha, Beta Valley, produced an inhibition zone of $18.3 \pm 0.3 \mathrm{~mm}$, and Sumra honey (H06) collected from Mukhwah exhibited an inhibition zone of $15.2 \pm 0.4 \mathrm{~mm}$ against MSSA at a $50 \%$ dilution in sterile distilled water. Variations also existed in other dilutions. Similarly, there was variation in the level of antibacterial activity of Sidr, Talha and Zahoor honeys against tested pathogens (Tables 2 and 3). The reason for variation in the potency of antibacterial activity of honey sharing a floral origin could be due to climatic conditions, soil composition and geographical areas of honey collection [26]. Variation in the level of antibacterial activity of honeys between different floral honey sources and within the same flora source has been reported in other studies as well $[40,41]$.

The positive control, a vancomycin disc $(30 \mu \mathrm{g})$, produced a $20.5 \pm 0.9 \mathrm{~mm}$ inhibition zone against MRSA and a $21.8 \pm 0.2 \mathrm{~mm}$ inhibition zone against MSSA, whereas the negative controls, catalase solution and sterile distilled water, did not produce any inhibition zone.

Sumra honey inhibited the growth of clinical isolates at $12 \pm 0.0$ dilution (v/v\%), and Manuka honey did so at $14 \pm 0.0$ dilution $(\mathrm{v} / \mathrm{v} \%)$, in the microbroth dilution assay (Table 4). This result means that Sumra honey has more total or synergistic antibacterial activity than Manuka honey. A statistically significant difference (Kruskal-Wallis test, $p=0.00$ ) was noted among the mean MICs of tested honeys against MRSA and ATCC reference strains. Moreover, there was also a statistically significant difference (Bonferroni post hoc test, $p=0.00$ ) between the mean MICs of Sumra honey and Manuka honey assayed against the tested pathogens (Table 5).

Table 2 Inhibition zone (mm) of honey samples at 50 and 25\% (w/v) dilutions in sterile purified water and 50 and 25\% (v/v) dilutions in catalase solution by agar well diffusion assay against MSSA

\begin{tabular}{|c|c|c|c|c|c|}
\hline \multirow{2}{*}{$\begin{array}{l}\text { Code } \\
\text { no. }\end{array}$} & \multirow{2}{*}{$\begin{array}{l}\text { Honey } \\
\text { samples }\end{array}$} & \multicolumn{4}{|c|}{ Zone of inhibition (mm) } \\
\hline & & $50 \%$ in water & $50 \%$ in catalase & $25 \%$ in water & $25 \%$ in catalase \\
\hline Standard & Manuka & $16.8 \pm 0.1$ & $15.4 \pm 0.4$ & $12.5 \pm 0.2$ & $11.1 \pm 0.1$ \\
\hline H01 & Sidr & $16.7 \pm 0.2$ & $N Z D^{a}$ & $11.3 \pm 0.2$ & NZD \\
\hline $\mathrm{H} 02$ & Talha & $11.3 \pm 0.0$ & NZD & $10.1 \pm 0.0$ & NZD \\
\hline $\mathrm{H} 03$ & Sumra & $18.3 \pm 0.3$ & $11.4 \pm 0.4$ & $13.0 \pm 0.0$ & NZD \\
\hline $\mathrm{HO}$ & Sidr & $16.9 \pm 0.1$ & NZD & $10.9 \pm 0.0$ & NZD \\
\hline H05 & Talha & $15.5 \pm 0.4$ & $11.8 \pm 0.3$ & $11.2 \pm 0.0$ & NZD \\
\hline H06 & Sumra & $15.2 \pm 0.4$ & NZD & $10.0 \pm 0.0$ & NZD \\
\hline $\mathrm{H} 07$ & Zahoor & $11.5 \pm 0.1$ & NZD & NZD & NZD \\
\hline H08 & Zahoor & $18.0 \pm 0.1$ & NZD & $12.0 \pm 0.0$ & NZD \\
\hline H09 & Zahoor & $13.9 \pm 0.2$ & NZD & $10.2 \pm 0.1$ & NZD \\
\hline $\mathrm{H} 11$ & Sidr & $14.1 \pm 0.2$ & NZD & $10.0 \pm 0.1$ & NZD \\
\hline
\end{tabular}

${ }^{\mathrm{a} N Z D ;}$ no zone detected 
Table 3 Inhibition zone $(\mathrm{mm})$ of honey samples at 50 and 25\% (w/v) dilutions in sterile purified water and 50 and 25\% (w/v) dilutions in catalase solution by agar well diffusion assay against MRSA

\begin{tabular}{|c|c|c|c|c|c|}
\hline \multirow{2}{*}{$\begin{array}{l}\text { Code } \\
\text { no. }\end{array}$} & \multirow{2}{*}{$\begin{array}{l}\text { Honey } \\
\text { samples }\end{array}$} & \multicolumn{4}{|c|}{ Zone of inhibition (mm) } \\
\hline & & $50 \%$ in water & $50 \%$ in catalase & $25 \%$ in water & $25 \%$ in catalase \\
\hline Standard & Manuka & $16.0 \pm 0.1$ & $14.9 \pm 0.0$ & $12.0 \pm 0.1$ & $11.1 \pm 0.1$ \\
\hline H01 & Sidr & $17.2 \pm 0.2$ & NZD ${ }^{a}$ & $10.2 \pm 0.2$ & NZD \\
\hline $\mathrm{H} 02$ & Talha & $13.4 \pm 0.1$ & NZD & $10.7 \pm 0.2$ & NZD \\
\hline $\mathrm{H} 03$ & Sumra & $18.1 \pm 0.1$ & $11.4 \pm 0.4$ & $13.0 \pm 0.0$ & NZD \\
\hline $\mathrm{HO}$ & Sidr & $17.2 \pm 0.4$ & NZD & $10.9 \pm 0.0$ & NZD \\
\hline H05 & Talha & $14.5 \pm 0.3$ & $11.8 \pm 0.3$ & $11.1 \pm 0.0$ & NZD \\
\hline H06 & Sumra & $14.5 \pm 0.3$ & NZD & $10.0 \pm 0.0$ & NZD \\
\hline $\mathrm{H} 07$ & Zahoor & $11.8 \pm 0.4$ & NZD & NZD & NZD \\
\hline H08 & Zahoor & $17.5 \pm 0.3$ & NZD & $11.1 \pm 0.1$ & NZD \\
\hline H09 & Zahoor & $12.8 \pm 0.3$ & NZD & NZD & NZD \\
\hline $\mathrm{H} 11$ & Sidr & $12.6 \pm 0.2$ & NZD & NZD & NZD \\
\hline
\end{tabular}

${ }^{\mathrm{a} N Z D ;}$ no zone detected

\section{Discussion}

Because of the increasing problem of antimicrobial resistance and on the basis of recent studies, honey is being integrated into modern medicine. There are several studies that reflect that a variety of beneficial effects of honey in wound healing originating from multiple bioactive compounds [42]. These effects encompass a wide range of benefits that are broad spectrum in nature, including avoidance of bacterial resistance, promotion of debridement and reduction in inflammation and malodour [9]. It is important to identify new honey with high therapeutic value for wound infections because a limited range of honey impregnated dressings are presently available, and they are quite expensive and not

Table 4 Minimum inhibitory concentrations (MICs) (\%v/v) of honeys against clinical isolates of MRSA and ATCC standard strains

\begin{tabular}{lllll}
\hline Code no. & Bacteria & Manuka & Sumra & Simulated \\
\hline 977414 & MRSA-sputum & $14 \pm 0.0^{*}$ & $12 \pm 0.0$ & $35 \pm 0.0$ \\
948815 & MRSA-pleural fluid & $14.6 \pm 0.5$ & $12 \pm 0.0$ & $35 \pm 0.0$ \\
930401 & MRSA-blood & $14 \pm 0.0$ & $12 \pm 0.0$ & $35 \pm 0.0$ \\
963905 & MRSA-blood & $14 \pm 0.0$ & $12 \pm 0.0$ & $35 \pm 0.0$ \\
897648 & MRSA-blood & $14 \pm 0.0$ & $12 \pm 0.0$ & $35 \pm 0.0$ \\
574577 & MRSA-eye swab & $14 \pm 0.0$ & $12 \pm 0.0$ & $35 \pm 0.0$ \\
979101 & MRSA-wound swab & $14 \pm 0.0$ & $12 \pm 0.0$ & $35 \pm 0.0$ \\
979638 & MRSA-skin swab & $14 \pm 0.0$ & $12 \pm 0.0$ & $35 \pm 0.0$ \\
495310 & MRSA-bronchial washing & $14 \pm 0.0$ & $12 \pm 0.0$ & $35 \pm 0.0$ \\
633489 & MRSA- wound swab & $14 \pm 0.0$ & $12 \pm 0.0$ & $35 \pm 0.0$ \\
ATCC 43300 & MRSA & $14 \pm 0.0$ & $12 \pm 0.0$ & $35 \pm 0.0$ \\
ATCC 29213 & MSSA & $14 \pm 0.0$ & $12 \pm 0.0$ & $35 \pm 0.0$ \\
ATCC 25922 & Escherichia coli & $15 \pm 0.0$ & $15 \pm 0.0$ & $30 \pm 0.0$ \\
\hline
\end{tabular}

*Mean of triplicate, with standard deviation easily available everywhere [43]. Therefore, more research is required to identify new sources of honey from different countries so that patients can be benefitted with inexpensive, easily accessible and locally produced products.

In Saudi Arabia, there are more than 300 bee-associated floral species, including trees, shrubs, vines and herbs. However, Sumra (Acacia tortilis), Talha (Acacia origena), Sidr (Ziziphus spina-christi), Dahiana (Acacia asak) and Lavendula species are the most important sources of honey production in the Taif, Al-Baha and Asir regions [44]. Both Acacia and Ziziphus species are drought and heat tolerant and are distributed in tropical and subtropical areas of Saudi Arabia [45]. Honey produced from Sidr trees is dark brown in colour and the is most popular and expensive because of its unique aroma and taste [46]. However, honey produced from Acacia species is consumed widely because of its medicinal and nutritive properties. Talha honey is light in colour (pale yellow), and Sumra honey is dark in colour (dark brown) [47].

Sumra (H03), Sidr (H04) and Zahoor (H08) honeys exhibited higher antibacterial activity in the agar well diffusion assay against MSSA at a 50\% dilution in sterile distilled water than Manuka honey (Table 2). Four local honeys exhibited more antibacterial activity against MRSA than Manuka honey, including Sumra (H03), Sidr (H04), Sidr (H01) and Zahoor (H08) honeys (Table 3). This result means that these honeys have high $\mathrm{H}_{2} \mathrm{O}_{2}$ activity in comparison with that of Manuka honey. In some previous studies, Beri, Jarrah, Buckwheat and Ulmo honeys were identified as possessors of high $\mathrm{H}_{2} \mathrm{O}_{2}$ _related antibacterial activity [26, 35, 48]. $\mathrm{H}_{2} \mathrm{O}_{2}$ is an important contributor to the antibacterial activity of honey and is present in variable concentrations in 
Table 5 Comparison of mean minimum inhibitory concentrations of Manuka, Sumra and simulated honey against MRSA

\begin{tabular}{|c|c|c|c|c|c|c|}
\hline \multirow[t]{2}{*}{ (I) Honey } & \multirow[t]{2}{*}{ (J) Honey } & \multirow{2}{*}{$\begin{array}{l}\text { Mean } \\
\text { Difference } \\
(I-J)\end{array}$} & \multirow{2}{*}{$\begin{array}{l}\text { Std. } \\
\text { Error }\end{array}$} & \multirow[t]{2}{*}{ Sig. } & \multicolumn{2}{|c|}{ 95\% Confidence interval } \\
\hline & & & & & Lower Bound & Upper Bound \\
\hline \multirow[t]{2}{*}{ Manuka honey } & Sumra honey & $1.8^{\mathrm{a}}$ & .37 & .000 & .95 & 2.8 \\
\hline & Simulated honey & $-20.4^{\mathrm{a}}$ & .37 & .000 & -21.4 & -19.5 \\
\hline \multirow[t]{2}{*}{ Sumra honey } & Manuka honey & $-1.8^{\mathrm{a}}$ & .37 & .000 & -2.8 & -.95 \\
\hline & Simulated honey & $-22.3^{\mathrm{a}}$ & .37 & .000 & -23.3 & -21.4 \\
\hline \multirow[t]{2}{*}{ Simulated honey } & Manuka honey & $20.4^{\mathrm{a}}$ & .37 & .000 & 19.5 & 21.4 \\
\hline & Sumra honey & $22.3^{\mathrm{a}}$ & .37 & .000 & 21.4 & 23.3 \\
\hline
\end{tabular}

${ }^{\mathrm{a}}$ The mean difference is significant at the 0.05 level

different honeys. However, the quantity of $\mathrm{H}_{2} \mathrm{O}_{2}$ present in honey is quite low $(0.002 \mathrm{M})$ compared to that present in disinfectants $(0.8$ to $8 \mathrm{M})$ [49]. This small quantity of $\mathrm{H}_{2} \mathrm{O}_{2}$ in honey is unable to cause bacterial lysis when used in isolation. However, it has been shown that bacterial DNA degradation and eventual bacterial lysis requires an interaction between non-peroxide factors of honey (polyphenols and transition metals) and $\mathrm{H}_{2} \mathrm{O}_{2}[50,51]$.

Apart from hydrogen peroxide, honey antimicrobial activity is also derived from other factors such as its acidity, high osmolarity and multiple non-peroxide plant-derived components [9, 52-55]. Recently, a number of bioactive compounds have been identified in honey with potent antibacterial properties. Important in this regard are methylglyoxal, leptosin, lysozyme, pinocembrin, 1,4-dihydroxybenzene and bee defensin-1 [52, 56-60]. The antibacterial activity of these substances is not destroyed by heat or catalase treatment, as hydrogen peroxide is. However, there is substantial variation in their concentration and presence in different honey samples [61].

The multiple antibacterial substances present in honey augment each other's activities and produce synergistic effects on multiple targets of pathogenic bacteria [9]. This phenomenon is the probable reason that bacterial resistance to honey is difficult and not yet reported. In comparison, antibiotics usually consist of a single compound and have only one target in bacteria; therefore, it is easier for bacteria to generate resistance in stressful conditions [62]. It is important to identify bioactive nonperoxide components in honey so that new antibiotics could be designed and developed based on natural synergistic interactions of different components present in honey.

Sumra (H03) honey collected from Al-Baha, Beta Valley, and Talha (H05) honey collected from Al-Baha, Baljurashi, also exhibited an inhibition zone against MSSA at a 50\% dilution in catalase solution in the agar well diffusion assay (Table 2). Since the catalase enzyme destroys hydrogen peroxide, both Sumra and Talha honeys possess non-peroxide antibacterial potential, similar to medically graded Manuka honey. However, their level of non-peroxide activity is low because they did not produce an inhibition zone at the 25\% dilution in catalase solution, as did Manuka honey (Tables 2 and 3). It is important to detect active ingredients causing non-peroxide activity in Sumra and Talha honeys in future studies. Both Sumra (H03) and Talha (H05) honeys also showed non-peroxide activity against MRSA (Table 3). There are limited numbers of honey brands available worldwide with non-peroxide antibacterial activity, and the most researched honeys in this regard are Manuka and Medihoney. The non-peroxide activity of Manuka honey originates from a plant-derived compound known as methylglyoxal [63].

We also used a microbroth dilution assay for the determination of MICs. The dilution assay provides more precise and quantitative results than the agar well diffusion assay [64]. The agar well diffusion assay is widely used for evaluating the antibacterial activity of honey against bacterial pathogens; however, the assay has a number of limitations. These include a lack of sensitivity; large-sized plant-derived bioactive compounds present in honey may not diffuse at all or diffuse very slowly, thus being missed by this technique [65]. For instance, polymyxin, a well-known antibiotic that consists of a large-sized molecule poorly diffuses in the diffusion test; therefore, more sensitive assays, such as the broth dilution assay or agar dilution assay, are used for testing [66]. As the diffusion of honey is slow and the honey sample is further diluted by diffusion into the agar, bacteria can grow on the outer area before the inhibitory substance reaches them [67]. Moreover, nonpolar substances may not readily diffuse through waterbased agar [68]. A study revealed that there is a lack of a clear relationship between zone size obtained through agar diffusion assay and MIC evaluation in dilution methods [39]. These reports highlight that the agar diffusion assay may not be the most appropriate method for assessing the antibacterial activity of honey [39]. The results obtained through the agar diffusion assay are not 
truly representative of the overall antibacterial activity of any honey. Therefore, in this study, we also used a microbroth dilution assay to determine the MICs of Sumra (H03), Manuka and simulated honey against ten clinical isolates of MRSA and three reference strains.

Although the difference in the MICs of Manuka honey and Sumra honey was statistically significant, its clinical relevance and significance are not clear. Presently, a limited range of honeys has been approved by health regulatory authorities for the treatment of infected wounds and partial-thickness burns, which include Manuka and Medihoney. A number of in vitro studies have shown that there is less than a $5 \%$ difference in MICs of certified honeys and noncertified honeys [69, 70]. Moreover, Blair et al. (2009) revealed that both UMF honey (Manuka honey) and non-UMF honey are equally effective in overcoming bacterial resistance [71]. The clinical significance of this difference in MICs can be evaluated in randomized controlled clinical trials of registered honeys versus non-registered honeys for the treatment of infected wounds and burns in future studies.

Sumra honey had a lower MIC (indicative of better antibacterial activity) than Manuka honey against all tested clinical isolates and reference strains, MRSA (ATCC 43300) and MSSA (ATCC 29213). An equivalent MIC $(15.0 \% \mathrm{v} / \mathrm{v})$ was observed for E. coli (ATCC 25922) between Manuka honey and Sumra honey. No difference in MIC was found for MRSA and MSSA. This finding means that honey is equally effective against both methicillin-sensitive and -resistant types of isolates and has a unique mechanism of action against pathogenic bacteria. Interestingly, bacterial resistance to honey has been not documented, and this unique characteristic of honey makes it a valuable therapeutic agent for multidrug-resistant or pandrugresistant pathogenic bacteria. This pattern was also observed in some previous studies [72, 73]. In comparison with previous studies, there is substantial variation among the MICs of Manuka honey for MRSA. For instance, a recently conducted study demonstrated that Manuka honey inhibited twenty-four MRSA isolates at $4.4 \%(\mathrm{v} / \mathrm{v})$ [73]. Similarly, another study demonstrated that the growth of five MRSA strains was inhibited by Manuka at a $12.5 \% \mathrm{v} / \mathrm{v}$ dilution [48]. The variation in the MIC of Manuka honey against the same bacteria could be due to differences in the methodology used for MIC determination or the potency of the Manuka honey used. The MIC of simulated honey was recorded between 30 and 35\% v/v (Table 4) against clinical isolates and ATCC reference strains. The results indicate that there are other factors besides sugar that contribute to the antibacterial activity of honey.

\section{Limitation of study}

Physiochemical characteristics of tested honeys could not be determined due to the unavailability of the facility.

\section{Conclusions}

Local honeys exhibited variable antibacterial activities against the tested pathogens. Sumra honey possesses better peroxide-based antibacterial activity than Manuka honey. Therefore, Sumra honey could be used as a potential therapeutic agent in those clinical conditions where additional peroxide activity is required. Moreover, it is important to conduct a large screening study in Saudi Arabia to identify honeys with high non-peroxide activity, such as Manuka honey.

\section{Abbreviations \\ ATCC: American Type Culture Collection; MIC: Minimum inhibitory concentration; MRSA: Methicillin-resistant Staphylococcus aureus; MSSA: Methicillin-sensitive Staphylococcus aureus; UMF: Unique Manuka factor}

\section{Acknowledgements \\ The authors gratefully acknowledge the DSR for technical and financial support. We are also thankful to Dr. Nadeem Shafeeque Butt for statistical analysis}

\section{Authors' contributions}

$\mathrm{MBH}, \mathrm{YMK}$ and ASA designed the study. YMK, MBH and ZU performed the experiments. $\mathrm{MBH}$ and $\mathrm{AAMJ}$ drafted the manuscript. All the authors approved the final manuscript.

\section{Funding}

This work was supported by the Deanship of Scientific Research (DSR), King Abdulaziz University, Jeddah, under grant no. (G-268-828-37). The authors, therefore, gratefully acknowledge the DSR for technical and financial support.

\section{Availability of data and materials}

The data and materials used in this study are available upon request from the authors.

Ethics approval and consent to participate

Not applicable

\section{Consent for publication}

Not applicable

\section{Competing interests}

The authors declare that they have no competing interests.

\section{Author details \\ ${ }^{1}$ Department of Microbiology, Faculty of Medicine, King Abdulaziz University, Rabigh Branch 21589, Saudi Arabia. ${ }^{2}$ Department of Medical Microbiology and Parasitology, Faculty of Medicine, King Abdulaziz University, Rabigh branch 21589, Saudi Arabia. ${ }^{3}$ Department of Surgery, Faculty of Medicine, King Abdulaziz University, Rabigh branch 21589, Saudi Arabia.}

Received: 4 December 2018 Accepted: 18 July 2019

Published online: 25 July 2019

\section{References}

1. Diekema DJ, Richter SS, Heilmann KP, Dohrn CL, Riahi F, Tendolkar S, McDanel JS, Doern GV. Continued emergence of USA300 methicillin -resistant Staphylococcus aureus in the United States: results from a nationwide surveillance study. Infect Control. 2014;35(03):285-92. 
2. Edris B, Reed JF. MRSA infection in lower extremity wounds. Int J Low Extrem Wounds. 2008;7(1):28-31.

3. Yousef SA, Mahmoud SY, Eihab MT. Prevalence of methicillin-resistant Staphylococcus aureus in Saudi Arabia: systemic review and meta-analysis. Afr J Clin Exp Microbiol. 2013;14(3):146-54.

4. Adam KM, Abomughaid MM. Prevalence of Methicillin-resistant Staphylococcus aureus in Saudi Arabia Revisited: A Meta-analysis. Open Public Health J. 2018:11(1):584-91.

5. Köck R, Becker K, Cookson B, van Gemert-Pijnen J, Harbarth S, Kluytmans J, Mielke M, Peters G, Skov R, Struelens M. Methicillin-resistant Staphylococcus aureus (MRSA): burden of disease and control challenges in Europe; 2010.

6. Fischbach MA, Walsh CT. Antibiotics for emerging pathogens. Science (New York, NY). 2009;325(5944):1089-93.

7. WHO: Antimicrobial resistance: global report on surveillance. 2014

8. Zumla A, Lulat A. Honey--a remedy rediscovered. J R Soc Med. 1989;82(7):384

9. Hussain MB. Role of honey in topical and systemic bacterial infections. J Altern Complement Med. 2018:24(1):15-24.

10. Saikaly SK, Khachemoune A. Honey and wound healing: an update. Am J Clin Dermatol. 2017;18(2):237-51.

11. Efem $\mathrm{S}$, Iwara $\mathrm{C}$. The antimicrobial spectrum of honey and its clinical significance. Infection. 1992;20(4):227-9.

12. Molan PC. Potential of honey in the treatment of wounds and burns. Am J Clin Dermatol. 2001;2(1):13-9.

13. Dunford C, Cooper R, Molan P. Using honey as a dressing for infected skin lesions. Nurs Times. 1999;96(14 Suppl):7-9.

14. Mohamed H, El Lenjawi B, Salma MA, Abdi S. Honey based therapy for the management of a recalcitrant diabetic foot ulcer. J Tissue Viability. 2014;23(1):29-33.

15. Moore OA, Smith LA, Campbell F, Seers K, McQuay HJ, Moore RA. Systematic review of the use of honey as a wound dressing. BMC Complement Altern Med. 2001;1(1):2.

16. Everett $\mathrm{E}$, Mathioudakis N. Update on management of diabetic foot ulcers. Ann N Y Acad Sci. 2018;1411(1):153-65.

17. Imran M, Hussain MB, Baig M. A randomized, controlled clinical trial of honey-impregnated dressing for treating diabetic foot ulcer. J Coll Physicians Surg Pak. 2015;25(10):721-5.

18. Yousaf I, Ishaq I, Hussain MB, Inaam S, Saleem S, Qamar MU. Antibacterial activity of Pakistani Beri honey compared with silver sulfadiazine on infected wounds: a clinical trial. J Wound Care. 2019;28(5):291-6.

19. Visavadia BG, Honeysett J, Danford MH. Manuka honey dressing: an effective treatment for chronic wound infections. Br J Oral Maxillofac Surg. 2008:46(1):55-6.

20. Jull AB, Cullum N, Dumville JC, Westby MJ, Deshpande S, Walker N. Honey as a topical treatment for wounds. Cochrane Database Syst Rev. 2015;(3):1131. Available from https://doi.org/10.1002/14651858.CD005083.pub4.

21. Jull A, Walker N, Parag V, Molan P, Rodgers A. Randomized clinical trial of honey-impregnated dressings for venous leg ulcers. $\mathrm{Br}$ I Surg. 2008;95(2):175-82.

22. Henriques A, Jenkins R, Burton N, Cooper R. The intracellular effects of manuka honey on Staphylococcus aureus. Eur J Clin Microbiol Infect Dis. 2010;29(1):45-50

23. Jenkins R, Burton N, Cooper R. Manuka honey inhibits cell division in methicillin-resistant Staphylococcus aureus. J Antimicrob Chemother. 2011; 66(11):2536-42.

24. Müller $P$, Alber DG, Turnbull L, Schlothauer RC, Carter DA, Whitchurch $C B$, Harry EJ. Synergism between Medihoney and rifampicin against methicillin-resistant Staphylococcus aureus (MRSA). PLoS One. 2013;8(2): e57679.

25. Simon A, Traynor K, Santos K, Blaser G, Bode U, Molan P. Medical honey for wound care-still the 'latest resort'? Evid Based Complement Alternat Med. 2009:6(2):165-73.

26. Hussain MB, Hannan A, Akhtar N, Fayyaz GQ, Imran M, Saleem S, Qureshi IA. Evaluation of the antibacterial activity of selected Pakistani honeys against multi-drug resistant Salmonella typhi. BMC Complement Altern Med. 2015;15(1):32.

27. Al-Ghamdi A, Nuru A. Beekeeping in the Kingdom of Saudi Arabia past and present practices. Bee World. 2013;90(2):26-9.

28. Halawani E, Shohayeb M. Survey of the antibacterial activity of Saudi and some international honeys. J Microbiol Antimicrob. 2011;3:94-101.

29. Alqurashi A, Masoud E, Alamin M. Antibacterial activity of Saudi honey against gram negative bacteria. J Microbiol Antimicrob. 2013;5(1):1-5.
30. Halawani EM, Shohayeb MM. Shaoka and Sidr honeys surpass in their antibacterial activity local and imported honeys available in Saudi markets against pathogenic and food spoilage bacteria. Aust J Basic Appl Sci. 2011;5:187-91.

31. Hegazi AG, Allah FA. Antimicrobial activity of different Saudi Arabia honeys. Glob Vet. 2012;9(1):53-9.

32. Ayaad TH, Shaker GH, Almuhnaa AM. Isolation of antimicrobial peptides from Apis florae and Apis carnica in Saudi Arabia and investigation of the antimicrobial properties of natural honey samples. J King Saud Univ Sci. 2012;24(2):193-200.

33. French V, Cooper RA, Molan PC. The antibacterial activity of honey against coagulase-negative staphylococci. J Antimicrob Chemother. 2005;56(1):228-31.

34. Allen $\mathrm{K}$, Molan P, Reid G. A survey of the antibacterial activity of some New Zealand honeys. J Pharm Pharmacol. 1991;43(12):817-22.

35. Irish J, Blair S, Carter DA. The antibacterial activity of honey derived from Australian flora. PLoS One. 2011;6(3):e18229.

36. Wayne P. Clinical and laboratory standards institute. Performance standards for antimicrobial susceptibility testing, vol. 17; 2007.

37. Cooper RA, Molan PC, Harding K. The sensitivity to honey of gram -positive cocci of clinical significance isolated from wounds. J Appl Microbiol. 2002;93(5):857-63.

38. Brudzynski K, Lannigan R. Mechanism of honey bacteriostatic action against MRSA and VRE involves hydroxyl radicals generated from honey's hydrogen peroxide. Front Microbiol. 2012;3:36.

39. Boorn K, Khor YY, Sweetman E, Tan F, Heard T, Hammer K. Antimicrobial activity of honey from the stingless bee Trigona carbonaria determined by agar diffusion, agar dilution, broth microdilution and time-kill methodology. J Appl Microbiol. 2010;108(5):1534-43.

40. Sousa JM, de Souza EL, Marques G, Meireles B, de Magalhães Cordeiro ÂT, Gullón B, Pintado MM, Magnani M. Polyphenolic profile and antioxidant and antibacterial activities of monofloral honeys produced by Meliponini in the Brazilian semiarid region. Food Res Int. 2016;84:61-8.

41. Matzen RD, Zinck Leth-Espensen J, Jansson T, Nielsen DS, Lund MN, Matzen $\mathrm{S}$. The antibacterial effect in vitro of honey derived from various danish flora. Dermatol Res Pract. 2018;2018:7021713.

42. Lusby P, Coombes A, Wilkinson J. Honey: a potent agent for wound healing? J Wound Ostomy Continence Nurs. 2002;29(6):295-300.

43. Seckam A, Cooper R. Understanding how honey impacts on wounds: an update on recent research findings. Wounds Int. 2013;4(1):20-4.

44. Al-Ghamdi A, Nuru A. Beekeeping in the Kingdom of Saudi Arabia opportunities and challenges. Bee World. 2013:90(3):54-7.

45. Adgaba N, Al-Ghamdi A, Tadesse Y, Getachew A, Awad AM, Ansari MJ, Owayss AA, Mohammed SEA, Alqarni AS. Nectar secretion dynamics and honey production potentials of some major honey plants in Saudi Arabia. Saudi J Biol Sci. 2017;24(1):180-91.

46. Adgaba N, Al-Ghamdi A, Shenkute A, Ismaiel S, Al-Kahtani S, Tadess Y, Ansari M, Abebe W, Abdulaziz M. Socio-economic analysis of beekeeping and determinants of box hive technology adoption in the Kingdom of Saudi Arabia. J Anim Plant Sci. 2014;24(6):1876-84.

47. Ahamed MME, Abdallah A, Abdalaziz A, Serag E, Atallah A-bEH. Some physiochemical properties of Acacia honey from different altitudes of the Asir region in southern Saudi Arabia. Czech J Food Sci. 2017;35(4): 321-7.

48. Sherlock O, Dolan A, Athman R, Power A, Gethin G, Cowman S, Humphreys H. Comparison of the antimicrobial activity of Ulmo honey from Chile and Manuka honey against methicillin-resistant Staphylococcus aureus, Escherichia coli and Pseudomonas aeruginosa. BMC Complement Altern Med. 2010;10(1):47.

49. Finnegan M, Linley E, Denyer SP, McDonnell G, Simons C, Maillard J-Y. Mode of action of hydrogen peroxide and other oxidizing agents: differences between liquid and gas forms. J Antimicrob Chemother. 2010;65(10):2108-15.

50. Brudzynski K, Abubaker K, St-Martin L, Castle A. Re-examining the role of hydrogen peroxide in bacteriostatic and bactericidal activities of honey. Front Microbiol. 2011:2:213.

51. Brudzynski K, Abubaker K, Miotto D. Unraveling a mechanism of honey antibacterial action: polyphenol induced oxidative effect on bacterial cell growth and on DNA degradation. Food Chem. 2012;133(2):329-36.

52. Kwakman PHS, Zaat SAJ. Antibacterial components of honey. IUBMB Life. 2012;64(1):48-55.

53. de Abreu Franchini RA, de Souza CF, Colombara R, Costa Matos MA, Matos RC. Rapid determination of hydrogen peroxide using peroxidase 
immobilized on Amberlite IRA-743 and minerals in honey. J Agric Food Chem. 2007:55(17):6885-90.

54. Molan PC. The evidence supporting the use of honey as a wound dressing. Int J Low Extrem Wounds. 2006;5(1):40-54.

55. Dustmann JH. Antibacterial effect of honey. Apiacta. 1979;14(1):7-11.

56. Kato Y, Umeda N, Maeda A, Matsumoto D, Kitamoto N, Kikuzaki H. Identification of a novel glycoside, leptosin, as a chemical marker of manuka honey. J Agric Food Chem. 2012;60(13):3418-23.

57. Kwakman PHS, De Boer L, Ruyter-Spira CP, Creemers-Molenaar T, Helsper J, Vandenbroucke-Grauls C, Zaat SAJ, Te Velde AA. Medical-grade honey enriched with antimicrobial peptides has enhanced activity against antibiotic -resistant pathogens. Eur J Clin Microbiol Infect Dis. 2011;30(2):251-7.

58. Adams CJ, Manley-Harris M, Molan PC. The origin of methylglyoxal in New Zealand manuka Leptospermum scoparium honey. Carbohydr Res. 2009;344(8):1050-3.

59. Majtan J, Klaudiny J, Bohova J, Kohutova L, Dzurova M, Sediva M, Bartosova M, Majtan V. Methylglyoxal-induced modifications of significant honeybee proteinous components in manuka honey: possible therapeutic implications. Fitoterapia. 2012;83(4):671-77.

60. Jaganathan SK, Mandal M. Antiproliferative effects of honey and of its polyphenols: a review. Biomed Res Int. 2009;2009:830616.

61. Oelschlaegel S, Gruner M, Wang P-N, Boettcher A, Koelling-Speer I, Speer K. Classification and characterization of manuka honeys based on phenolic compounds and methylglyoxal. J Agric Food Chem. 2012;60(29):7229-37.

62. Martínez JL, Baquero F. Interactions among strategies associated with bacterial infection: pathogenicity, epidemicity, and antibiotic resistance. Clin Microbiol Rev. 2002;15(4):647-79.

63. Mavric E, Wittmann S, Barth G, Henle T. Identification and quantification of methylglyoxal as the dominant antibacterial constituent of Manuka (Leptospermum scoparium) honeys from New Zealand. Mol Nutr Food Res. 2008;52(4):483-9.

64. Espinel-Ingroff A. Comparison of three commercial assays and a modified disk diffusion assay with two broth microdilution reference assays for testing zygomycetes, Aspergillus spp., Candida spp., and Cryptococcus neoformans with posaconazole and amphotericin B. J Clin Microbiol. 2006;44(10):3616-22.

65. Ivanov II, Honda K. Intestinal commensal microbes as immune modulators. Cell Host Microbe. 2012;12(4):496-508.

66. Petrof E, Claud E, Gloor G, Allen-Vercoe E. Microbial ecosystems therapeutics: a new paradigm in medicine? Benefic Microbes. 2012;4(1):53-65.

67. Pongtharangkul T, Demirci A. Evaluation of agar diffusion bioassay for nisin quantification. Appl Microbiol Biotechnol. 2004;65(3):268-72.

68. Griffin SG, Wyllie SG, Markham JL, Leach DN. The role of structure and molecular properties of terpenoids in determining their antimicrobial activity. Flavour Fragr J. 1999;14(5):322-32.

69. Lusby PE, Coombes AL, Wilkinson JM. Bactericidal activity of different honeys against pathogenic bacteria. Arch Med Res. 2005;36(5):464-7.

70. Willix DJ, Molan PC, Harfoot CG. A comparison of the sensitivity of woundâ€ infecting species of bacteria to the antibacterial activity of manuka honey and other honey. J Appl Bacteriol. 1992;73(5):388-94.

71. Blair SE, Cokcetin NN, Harry EJ, Carter DA. The unusual antibacterial activity of medical-grade Leptospermum honey: antibacterial spectrum, resistance and transcriptome analysis. Eur J Clin Microbiol Infect Dis. 2009;28(10):1199-208.

72. Lin SM, Molan PC, Cursons RT. The controlled in vitro susceptibility of gastrointestinal pathogens to the antibacterial effect of manuka honey. Eur J Clin Microbiol Infect Dis. 2011;30(4):569-74.

73. Hussain MB, Hannan A, Absar M, Butt N. In-vitro susceptibility of methicillin -resistant Stayphylococcus aureus to honey. Complement Ther Clin Pract. 2017;27:57-60.

\section{Publisher's Note}

Springer Nature remains neutral with regard to jurisdictional claims in published maps and institutional affiliations.

Ready to submit your research? Choose BMC and benefit from:

- fast, convenient online submission

- thorough peer review by experienced researchers in your field

- rapid publication on acceptance

- support for research data, including large and complex data types

- gold Open Access which fosters wider collaboration and increased citations

- maximum visibility for your research: over $100 \mathrm{M}$ website views per year

At BMC, research is always in progress.

Learn more biomedcentral.com/submissions 